\title{
Performance of the anammox sequencing batch reactor treating synthetic and real landfill leachate
}

\author{
Mariusz Tomaszewski ${ }^{1,}{ }^{*}$, Grzegorz Cema ${ }^{1}$, Tomasz Twardowski ${ }^{1}$ and Aleksandra \\ Ziembińska-Buczyńska ${ }^{1}$ \\ ${ }^{1}$ Silesian University of Technology, Faculty of Energy and Environmental Engineering, \\ Environmental Biotechnology Department, Akademicka 2, 44-100 Gliwice, Poland
}

\begin{abstract}
The anaerobic ammonium oxidation (anammox) process is one of the most energy efficient and environmentally-friendly bioprocess for the treatment of the wastewater with high nitrogen concentration. The aim of this work was to study the influence of the high nitrogen loading rate (NLR) on the nitrogen removal in the laboratory-scale anammox sequencing batch reactor (SBR), during the shift from the synthetic wastewater to landfill leachate. In both cases with the increase of NLR from 0.5 to $1.1-1.2 \mathrm{~kg}$ $\mathrm{N} / \mathrm{m}^{3} \mathrm{~d}$, the nitrogen removal rate (NRR) increases to about $1 \mathrm{~kg} \mathrm{~N} / \mathrm{m}^{3} \mathrm{~d}$, but higher NLR caused substrates accumulation and affects anammox process efficiency. Maximum specific anammox activity was determined as $0.638 \mathrm{~g}$ $\mathrm{N} / \mathrm{g}$ VSS $\cdot \mathrm{d}\left(\mathrm{NRR} 1.023 \mathrm{~kg} \mathrm{~N} / \mathrm{m}^{3} \cdot \mathrm{d}\right.$ ) and $0.594 \mathrm{~g} \mathrm{~N} / \mathrm{g}$ VSS $\cdot \mathrm{d}(\mathrm{NRR} 1.241 \mathrm{~kg}$ $\mathrm{N} / \mathrm{m}^{3} \cdot \mathrm{d}$ ) during synthetic and real wastewater treatment, respectively. Both values are similar and this is probably the nitrogen removal capacity of the used anammox biomass. This indicates, that landfill leachate did not influence the nitrogen removal capacity of the anammox process.
\end{abstract}

\section{Introduction}

The anaerobic ammonium oxidation (anammox) process is one of the most energy efficient and environmentally-friendly bioprocess for the removal of nitrogenous contaminants from wastewater. In the anammox process, ammonia nitrogen is anaerobically oxidised to molecular nitrogen, with the nitrite used as an electron acceptor, by an unique bacterial phylum - Planctomycetes. To achieve adequate ammonium: nitrite ratio (1:1.32), only part of ammonium must be oxidized to nitrite in partial nitritation process. Therefore, anammox is a beneficial alternative to the widespread nitrification and denitrification combination. The nitritation-anammox process helps to reduce significantly the oxygen demand (by ca. 60\%) and to eliminate the need for an organic carbon source. As a consequence, it reduces operational costs (up to $60 \%$ ), what is one of the most important advantages. The other advantages over the nitrification-denitrification system are: higher nitrogen removal rate, lower bioreactor volume, lower greenhouse gasses emission and lower excess sludge production (by 90\%) [1]. Anammox process is particularly suitable for the treatment of

\footnotetext{
${ }^{*}$ Corresponding author: mariusz.tomaszewski@polsl.pl
} 
wastewater with high nitrogen concentration and a deficiency in organic carbon. There are more than one hundred full scale applications of anammox-based technologies [2]. For optimal functioning, anammox bacteria require stable and specific conditions. The most influencing and crucial factors include: dissolved oxygen, $\mathrm{pH}$, temperature, redox potential and substrate concentration [3]. Free ammonia and nitrites can strongly inhibit anammox process [3]. For these reason, substrate concentration and nitrogen loading rate (NLR) control is an important strategy to preventing process inhibition.

The majority of the reported studies on substrate inhibition have been performed on anammox bacteria grown with mineral medium (synthetic wastewater) [4]. The applicability of the anammox process has been widely demonstrated with a variety of wastewater with high nitrogen concentration, such as: sludge digester effluent, reject water streams or landfill leachate $[2,4]$. The real wastewater, such as landfill leachate, has a very complex composition, with a variety of organics and salts. Landfill leachate contains a high concentrations of ammonia, low concentrations of biodegradable organic fraction matter and is characterised by a low Biochemical Oxygen Demand (BOD) to Chemical Oxygen Demand (COD) ratio. In consequence, an effective treatment of this kind of wastewater requires various, complicated processes, which make it very expensive $[5,6]$. The use of anammox process to treat this highly contaminated wastewater requires adaptation of the biomass. However, up to now treatment of landfill leachate via anammox process was reported only by few studies [6].

Therefore, the aim of this work was to study the influence of the high NLR on the nitrogen removal in the anammox sequencing batch reactor (SBR), during the shift from the synthetic wastewater to landfill leachate, with a more complex composition.

\section{Materials and methods}

\subsection{Synthetic and real landfill leachate}

The composition of the synthetic wastewater, prepared in tap water, was adapted from van de Graaf et al. [7]. Total NLR was regulated by $\mathrm{NH}_{4} \mathrm{Cl}$ and $\mathrm{NaNO}_{2}$ addition, while other elements were dosed in constant concentrations per liter: $0.048 \mathrm{~g} \mathrm{KHCO}_{3}, 0.041 \mathrm{~g} \mathrm{KH}_{2} \mathrm{PO}_{4}$, $0.228 \mathrm{~g} \mathrm{MgSO}_{4} \cdot 7 \mathrm{H}_{2} \mathrm{O}, 0.007 \mathrm{~g} \mathrm{FeSO}_{4} \cdot 7 \mathrm{H}_{2} \mathrm{O}, 0.004 \mathrm{~g}$ EDTA. Ammonium, nitrite and nitrate concentrations were $210-550 \mathrm{mg} \mathrm{N} / \mathrm{L}, 250-700 \mathrm{mg} \mathrm{N} / \mathrm{L}$ and $4-53 \mathrm{mg} \mathrm{N} / \mathrm{L}$, respectively. Organic carbon was not dosed.

The real landfill leachate used for this experiment was taken from the municipal landfill in the Southern Poland. Ammonium concentration was regulated by wastewater dilution with tap water. To achieve adequate ammonium : nitrites ratio $(1: 1.32), \mathrm{NaNO}_{2}$ has been added, what simulated the wastewater after partial nitritation process. Characteristics of the prepared real wastewater is presented in table 1 . Anammox bacteria are chemoautotrophic with $\mathrm{CO}_{2}$ as the main carbon source, while real wastewater contains also organic carbon. Too high concentrations of organic matter can limit anammox bacteria, which are unable to compete with heterotrophic denitrifying bacteria [10]. Influent chemical oxygen demand and total nitrogen $(\mathrm{COD} / \mathrm{TN})$ ratio during landfill leachate treatment ranged between 1.4 and 2.6, what does not affect anammox process efficiency significantly, but can improve NRR via denitrification [4]. 
Table 1 Composition of the real wastewater fed to the sequence batch reactor (SBR). TN - total nitrogen, COD - chemical oxygen demand, BOD- biological oxygen demand, TSS - total.

\begin{tabular}{c|c}
\multicolumn{2}{c}{ susspended solids. } \\
Parameter & Range $[\mathrm{mg} / \mathrm{L}]$ \\
\hline $\mathrm{TN}$ & $547-1391$ \\
$\mathrm{~N}^{-N_{4}}$ & $210-630$ \\
$\mathrm{~N}_{4} \mathrm{NO}_{2}$ & $330-800$ \\
$\mathrm{~N}^{-N_{3}}$ & $6-14$ \\
$\mathrm{COD}$ & $855-2850$ \\
$\mathrm{BOD}$ & $30-360$ \\
$\mathrm{Cl}$ & \\
$\mathrm{P}-\mathrm{PO}$ & \\
$\mathrm{TSS}$ & $280-2130$ \\
$\mathrm{COD} / \mathrm{TN}$ ratio & $129-617$ \\
\end{tabular}

\subsection{Reactor operation}

The experiment described in this paper was conducted in a SBR with a working volume of $20 \mathrm{~L}$. Prior to this work the biomass was used in other studies [8] and the reactor had been in operation for 550 days. The anammox suspended biomass was dominated by anammox bacteria of the genus Candidatus Jettenia (which was evaluated based on a metagenomic analysis - data not shown). Reactor was operated at a temperature of $28-36^{\circ} \mathrm{C}, \mathrm{pH} 7.0-8.6$, hydraulic retention time (HRT) equal 1 day, dissolved oxygen below $0.1 \mathrm{mg} / \mathrm{L}$ and $1.0-1.8$ $\mathrm{g} / \mathrm{L}$ of volatile suspended solids (VSS). Sludge retention time (SRT) was not regulated and range between 8 and 41 days. $\mathrm{pH}$ was corrected using $10 \% \mathrm{HCl}$ or $10 \% \mathrm{NaOH}$. Synthetic wastewater was changed to real wastewater in 288 day of the experiment.

\subsection{Analytical methods}

Regular measurements of ammonium, nitrite and nitrate nitrogen, chemical oxygen demand, chlorides and phosphorus were conducted using fast photometric tests (MERCK Millipore) with a photometer (MERCK Spectroquant ${ }^{\circledR}$ NOVA60). Temperature and $\mathrm{pH}$ was monitored by JUMO tecLine HD - pH combination electrode. Dissolved oxygen concentration was measured by ELMETRON Conductivity/Oxygen Meter CCO-505 with ELMETRON COG1 oxygen sensor. The concentration of VSS was measured according to standard method [9].

\section{Results and discussion}

Course of the experiment could be divided into four phases: (I) $1-65 \mathrm{~d}$ : stable operation on synthetic wastewater, (II) 66 - $203 \mathrm{~d}$ : NLR increase and activity restoration on synthetic wastewater, (III) $204-287 \mathrm{~d}$ : stable operation on synthetic wastewater, (IV) $288-407 \mathrm{~d}$ : NLR increase and activity restoration on landfill leachate. The overall performance of the reactor is depicted in the figures 1 and 2 .

In phase I reactor was operated with average NLR $0.634 \pm 0.026 \mathrm{~kg} \mathrm{~N} / \mathrm{m}^{3} \mathrm{~d}$ (standard deviation, SD) and NRR $0.504 \pm 0.030 \mathrm{~kg} \mathrm{~N} / \mathrm{m}^{3} \mathrm{~d}(\mathrm{SD})$. During phase II NLR was gradually 
increased to $1.243 \mathrm{~kg} \mathrm{~N} / \mathrm{m}^{3} \mathrm{~d}$ on day 121 . Average nitrogen removal efficiency between 66 and 121 day remained stable at $84 \pm 3 \%$ (SD). After this time, ammonium and nitrite start accumulating in the reactor, and nitrogen removal efficiency dramatically dropped to $44 \%$ on day 128. Substrate inhibition of the anammox bacteria is well known phenomenon [2, 3, 10]. Free ammonia (FA) or un-ionized ammonia $\left(\mathrm{NH}_{3}\right)$ and free nitrous acid $\left(\mathrm{HNO}_{2}\right)$ or nitrite ion $\left(\mathrm{NO}_{2}{ }^{-}\right)$, has been suggested to have a negative effect on anammox process. They diffuses through the cell membrane into the cell and changes the cytoplasmic $\mathrm{pH}$, neutralizing the membrane potential, which may cause cell death. On day 128, concentrations of free ammonia and nitrite increased to 39 and $245 \mathrm{mg} / \mathrm{L}$, respectively. To maintain a stable operation of the anammox process, the free ammonia concentration should be less than $20-$ $25 \mathrm{mg} / \mathrm{L}$, whereas nitrites can inhibit anammox in concentrations above $100 \mathrm{mg} \cdot \mathrm{L}^{-1}$, or less [3].

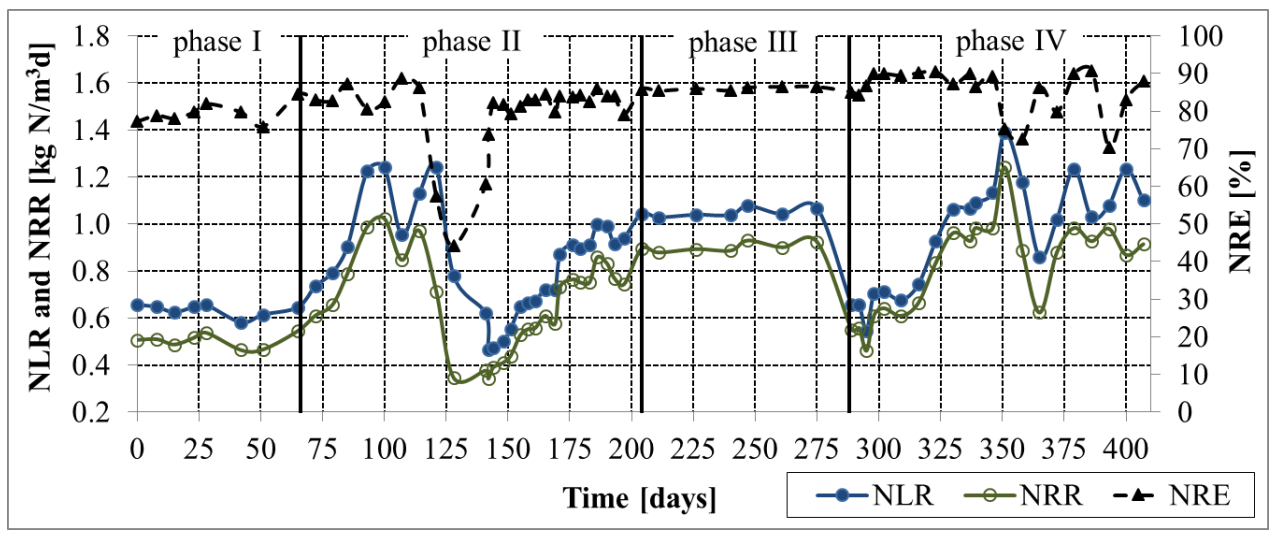

Fig. 1. Performance of the sequencing batch reactor (SBR). NLR - nitrogen loading rate, NRR nitrogen removal rate, NRE - nitrogen removal efficiency.

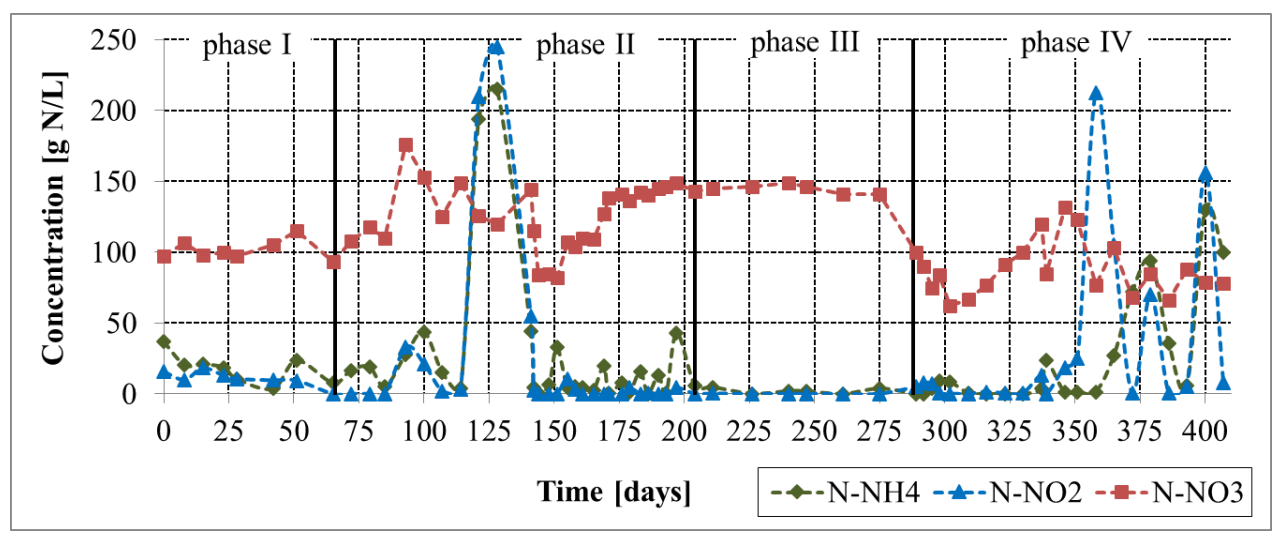

Fig. 2. Concentrations of the ammonium nitrogen $\left(\mathrm{N}-\mathrm{NH}_{4}\right)$, nitrite nitrogen $\left(\mathrm{N}-\mathrm{NO}_{2}\right)$ and nitrate nitrogen $\left(\mathrm{N}-\mathrm{NO}_{3}\right)$ in the sequence batch reactor (SBR) effluent.

However, maximum NRR $\left(1.023 \mathrm{~kg} \mathrm{~N} / \mathrm{m}^{3} \mathrm{~d}\right)$ and specific anammox activity $(0.638 \mathrm{~g} \mathrm{~N} / \mathrm{g}$ VSS $d$ ) achieved in this work was in the range reported by other studies [11-14]. Similar research where SBR was fed with high nitrogen load synthetic wastewater, was described by Lopez et al. [11]. During 139 days, NLR was gradually increased from 0.25 to $1.60 \mathrm{~kg} \mathrm{~N} / \mathrm{m}^{3} \mathrm{~d}$, and maximum specific anammox activity was $0.92 \mathrm{~g} \mathrm{~N} / \mathrm{g} \mathrm{VSS} \cdot \mathrm{d}$, but at slightly higher 
temperature $\left(36^{\circ} \mathrm{C}\right)$. To restore anammox process efficiency, NLR was decreased to 0.464 $\mathrm{kg} \mathrm{N} / \mathrm{m}^{3} \mathrm{~d}$. Then, it was again gradually increased and achieved during phase III average value of $1.048 \pm 0.018 \mathrm{~kg} \mathrm{~N} / \mathrm{m}^{3} \mathrm{~d}(\mathrm{SD})$. During this 83 days of phase III, stable and high nitrogen removal efficiency of $86 \pm 1 \%$ (SD), with NRR $0.901 \pm 0.019 \mathrm{~kg} \mathrm{~N} / \mathrm{m}^{3} \mathrm{~d}$ (SD) was maintained. Process was operated in these stable conditions until real wastewater was introduced in the last phase.

The anammox SBR treated municipal landfill leachate from day 288 to 407 (phase IV). The feeding strategy was based on increase of the NLR when the nitrogen removal efficiency was stable. From day 288 to 346 NLR was gradually increased from 0.656 to $1.134 \mathrm{~kg} \mathrm{~N} / \mathrm{m}^{3} \mathrm{~d}$. Average nitrogen removal efficiency during this period remained stable at $88 \pm 2 \%$ (SD). Stable and high NRR of $0.901 \pm 0.019 \mathrm{~kg} \mathrm{~N} / \mathrm{m}^{3} \mathrm{~d}$ (SD), with specific anammox activity $(0.521$ $\pm 0.016 \mathrm{~g} \mathrm{~N} / \mathrm{g} \mathrm{VSS} \cdot \mathrm{d}$ ) was maintained from 330 to 350 day of the experiment. Nitrogen removal was probably improved by the denitrification, which existed simultaneously in the bioreactor [2], what can be proved by COD and nitrate removal. Average ratio of nitrate produced to ammonium consumed was between $0.13-0.20$, what is lower than proposed for anammox process stoichiometric value (0.26) [1]. When NLR achieved $1.391 \mathrm{~kg} \mathrm{~N} / \mathrm{m}^{3} \mathrm{~d}$ on day 351 , ammonium is consumed, but nitrites starts accumulating and achieved concentration of $231 \mathrm{mg} / \mathrm{L}$. This affects anammox process efficiency by the nitrite inhibition. It has been reported that nitrites can inhibit anammox in concentrations above $100 \mathrm{mg} \cdot \mathrm{L}^{-1}$, or less [3]. After this time NLR was decreased to $0.859 \mathrm{~kg} \mathrm{~N} / \mathrm{m}^{3} \mathrm{~d}$ in day 365 . From day 372 to the end of the experiment NRR remained stable at $0.926 \pm 0.049 \mathrm{~kg} \mathrm{~N} / \mathrm{m}^{3} \mathrm{~d}(\mathrm{SD})$, in the range of NRR obtained in phase III and between days 330 and 350, but NLR increase caused substrates accumulation at the effluent (Fig. 1 and 2). These results suggest, that this is the highest NLR for stable process operation. Maximum NRR was determined as $1.241 \mathrm{~kg} \mathrm{~N} / \mathrm{m}^{3} \mathrm{~d}$ and 1.023 $\mathrm{kg} \mathrm{N} / \mathrm{m}^{3} \mathrm{~d}$, during landfill leachate and synthetic wastewater treatment, respectively. However, higher NRR during phase IV was caused by higher biomass concentration, because maximum specific anammox activity $(0.594 \mathrm{~g} \mathrm{~N} / \mathrm{g}$ VSS $\cdot \mathrm{d})$ achieved in phase IV were similar to that of phase II $(0.638 \mathrm{~g} \mathrm{~N} / \mathrm{g}$ VSS $\cdot \mathrm{d})$. This is probably the nitrogen removal capacity of tested anammox biomass. Slightly lower activity of the biomass cultivated on real wastewater (phase IV), than on synthetic wastewater (phase II) could be caused by two factors. The inhibitory effect of nitrite, which is stronger in the absence of ammonium [15], and the content of the other inhibitors in the landfill leachate, such as heavy metals [16]. Up to now, several works have already described performance of the anammox process treating municipal landfill leachate. Reported NLRs and nitrogen removal efficiencies ranged from 0.1 to $2.4 \mathrm{~kg} \mathrm{~N} / \mathrm{m}^{3} \mathrm{~d}$ and from 60 to $89 \%$, respectively [13, 16-18]. The highest $89 \%$ nitrogen removal efficiency, with NLR $2.4 \mathrm{~kg} \mathrm{~N} / \mathrm{m}^{3} \mathrm{~d}$, were achieved in a $2 \mathrm{~L}$ granular SBR [18].

The effect of the NLR on the NRR during synthetic and real wastewater treatment is depicted in figure 3. The same behavior has been observed in both cases. With the increase of NLR from 0.5 to $1.1-1.2 \mathrm{~kg} \mathrm{~N} / \mathrm{m}^{3} \mathrm{~d}$, the NRR increases to about $1 \mathrm{~kg} \mathrm{~N} / \mathrm{m}^{3} \mathrm{~d}$, but higher NLR affects anammox process efficiency. This indicates, that landfill leachate did not influence on the nitrogen removal capacity of the anammox process. This is in line with the observation described by Scaglione et al. [4]. They assessed nitrite inhibition on granular anammox biomasses from the two SBRs, treating synthetic wastewater and real landfill leachate. Response to increasing concentration of nitrite was very similar, regardless of the type of wastewater. 

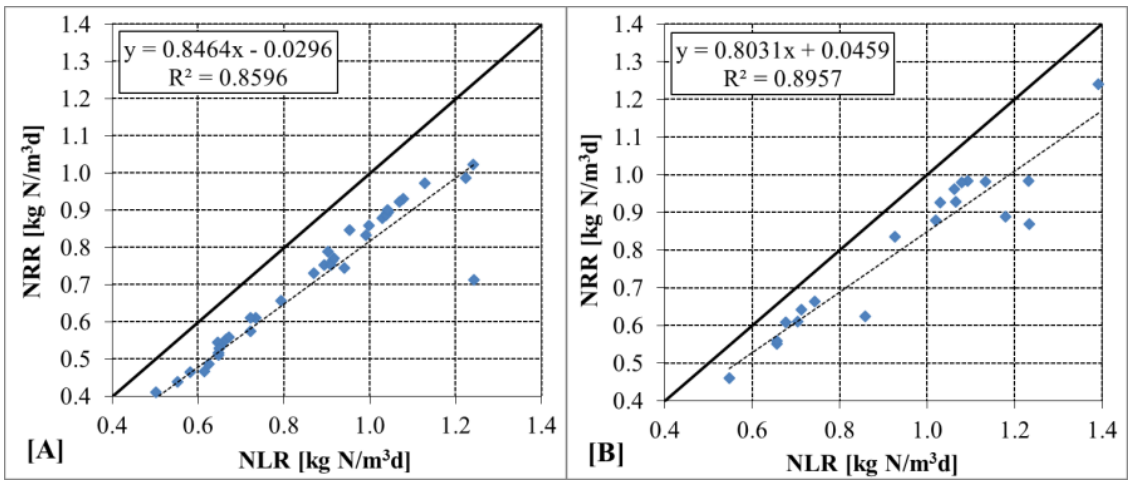

Fig. 3. Effect of nitrogen loading rate (NLR) on nitrogen removal rate (NRR) during synthetic $[A]$ and real $[\mathrm{B}]$ wastewater treatment.

\section{Conclusions}

Anammox process performed on very different wastewater (synthetic and real landfill leachate) presented very similar response to high NLR in the anammox SBR. In both cases with the increase of NLR to $1.1-1.2 \mathrm{~kg} \mathrm{~N} / \mathrm{m}^{3} \mathrm{~d}$, the NRR increases to about $1 \mathrm{~kg} \mathrm{~N} / \mathrm{m}^{3} \mathrm{~d}$. However, higher NLR caused substrates accumulation and inhibition of the anammox process. After decreasing of NLR, process efficiency recovered, what suggests that moderate loading shocks in the continuous anammox reactor can be solved by stopping the feeding to allow the consumption of the accumulated substrates. Probably nitrogen removal capacity of used anammox biomass was determined as $0.638 \mathrm{~g} \mathrm{~N} / \mathrm{g}$ VSS $\cdot \mathrm{d}\left(\mathrm{NRR} 1.023 \mathrm{~kg} \mathrm{~N} / \mathrm{m}^{3} \cdot \mathrm{d}\right.$ ) and $0.594 \mathrm{~g} \mathrm{~N} / \mathrm{g} \mathrm{VSS} \cdot \mathrm{d}\left(\mathrm{NRR} 1.241 \mathrm{~kg} \mathrm{~N} / \mathrm{m}^{3} \cdot \mathrm{d}\right.$ ), during synthetic and real wastewater treatment, respectively. This indicates, that tested landfill leachate did not influence on the nitrogen removal capacity of the anammox process in this study.

Acknowledgements: work was founded by the Polish National Science Centre: UMO2013/09/D/NZ9/02438 and supported by The Silesian University of Technology: 08/080/BK-17/0045.

\section{References}

1. M. Tomaszewski, G. Cema, A. Ziembińska-Buczyńska. Chemosphere, 182, 203-214, (2017)

2. M. Ali, S. Okabe. Chemosphere, 141, 144-153, (2015)

3. R.-C. Jin, G.-F. Yang, J.-J. Yu, P. Zheng. Chem. Eng. J., 197, 67-79, (2012)

4. D. Scaglione, M. Ruscalleda, E. Ficara, M.D. Balaguer, J. Colprim. Chem. Eng. J., 209, 62-68, (2012)

5. K. Kaczorek, S. Ledakowicz. Bioprocess and Biosystems Engineering, 29, 291-304, (2006)

6. G. Cema, A. Sochacki: Treatment of Landfill Leachate by Anammox Process. In book: Technologies for the Treatment and Recovery of Nutrients from Industrial Wastewater, Chapter: 11, Publisher: IGI Global, Editors: Ángeles Val del Río, José Luis Campos Gómez, Anuska Mosquera Corral, 290-311, (2017)

7. A.A. Van de Graaf, P. de Bruijn, L.A. Robertson, M.S.M. Jetten, J.G. Kuenen. Microbiology, 142, 2187-2196, (1996)

8. M. Tomaszewski, G. Cema, A. Ziembińska-Buczyńska. Chemosphere, 185, 439-444, (2017) 
9. APHA: Standard methods for the examination of water and wastewater. 20th ed. Washington (DC), American Water Works Association (AWWA) \& Wat. Env. Fed. (WEF), (2005)

10. B. Ma, Y. Peng, S. Zhang, J. Wang, Y. Gan, J. Chang, S. Wang, G. Zhu. Bioresour. Technol., 129, 606-611, (2013)

11. H. Lopez, S. Puig, R. Ganigue, M. Ruscalleda, M.D. Balaguer, J. Colprim. J. Chem. Technol. Biotechnol., 83, 233-241, (2008)

12. S.S. Shalini, K. Joseph. Waste Management, 32, 2385-2400, (2012)

13. S.S. Shalini, K. Joseph. Bioresource Technology, 149, 474-485, (2013)

14. J. Liu, J. Zuo, Y. Yang, S. Zhu, S. Kuang, K. Wang. Journal of Environmental Sciences, 22(5), 777-783, (2010).

15. J.M. Carvajal-Arroyo, D. Puyol, L. Guangbin, A. Lucero-Acuna, R. Sierra-Alvarez, J.A. Field. Water Research, 48, 52-60, (2014)

16. Z. Liang, J. Liu. Journal of Hazardous Materials, 151, 202-212, (2008)

17. H. Zhang, S. Zhou. J. Cent. South Univ. Technol., 06, 663-667, (2006)

18. M. Ruscalleda, H. Lopez, R. Ganigue, S. Puig, M.D. Balaguer, J. Colprim. Water Science \& Technology, 58.9, 1749-1755, (2008) 